\title{
Hubungan Fungsi Keluarga dengan Status Gizi Anak di Kecamatan Soreang Kabupaten Bandung pada Tahun 2016
}

\author{
Ulfi Ainun Hanifah ${ }^{1}$, Nita Arisanti², Dwi Agustian², Dany Hilmanto ${ }^{3}$ \\ ${ }^{1}$ Fakultas Kedokteran, Universitas Padjadjaran \\ ${ }^{2}$ Departemen Ilmu Kesehatan Masyarakat, Fakultas Kedokteran Universitas Padjdajaran \\ ${ }^{3}$ Departemen Ilmu Kesehatan Anak, Fakultas Kedokteran Universitas Padjadjaran/ Rumah Sakit Umum Pusat \\ Dr. Hasan Sadikin Bandung
}

\begin{abstract}
Abstrak
Malnutrisi merupakan salah satu masalah kesehatan yang dialami oleh kebanyakan negara berkembang yang dapat disebabkan oleh faktor langsung maupun tidak langsung salah satunya faktor keluarga. Setiap keluarga memiliki fungsi keluarga yang dapat memberi pengaruh terhadap aspek kehidupan setiap anggotanya. Penelitian ini bertujuan mencari hubungan antara fungsi internal dan eksternal keluarga terhadap status gizi anak di Kecamatan Soreang, Kabupaten Bandung Tahun 2016. Penelitian ini merupakan penelitian dengan metode potong lintang yang melibatkan 251 pasangan ibu dan anak balita di Kecamatan Soreang, Kabupaten Bandung Tahun 2016. Data penelitian diambil pada bulan September- November 2016 dengan pengisian kuesioner APGAR serta SCREEM oleh responden untuk menilai fungsi keluarga dan melakukan pengukuran berat serta tinggi badan balita untuk menentukan nilai $\mathrm{Z}$ score (berat terhadap tinggi) sebagai status gizi balita. Selanjutnya hubungan keduanya dianalisis menggunakan perhitungan koefisien korelasi spearman. Tidak terdapat hubungan yang signifikan pada fungsi internal keluarga $(\mathrm{p}=0,304 ; \mathrm{r}=-0,065)$ dan fungsi ekternal keluarga $(\mathrm{p}=0,116 ; \mathrm{r}=-0,100)$ terhadap status gizi anak. Dapat disimpulkan bahwa dalam penelitian ini, fungsi keluarga tidak memberikan pengaruh pada status gizi anak di Kecamatan Soreang, Kabupaten Bandung. Penelitian mengenai fungsi keluarga dengan menggunakan instrumen kuesioner APGAR Keluarga dan SCREEM dibutuhkan proses analisis yang lebih lanjut.
\end{abstract}

Kata Kunci : APGAR keluarga, Fungsi Keluarga, SCREEM, Status Gizi Anak

\section{Correlation between Family Function with Nutritional Status of Children in Soreang District Bandung 2016}

\begin{abstract}
Malnutrition is one of the health problems especially the developing countries which can caused by various factors, both direct and indirect factors such as family factor. Every family has a family function that can effect to all aspects of life for every family member. This study aimed to find the correlation between the internal and external family function on the nutritional status of children in the District Soreang, Bandung in 2016. This research is a cross sectional study involving 251 pairs of mothers and children under five in the District Soreang, Bandung in 2016. Data collection start from September until November 2016, where the respondens should answer the family APGAR and SCREEM questionnaires to assess their family function. We also measure the weight and height of their children to determine the value of $Z$ score (weight to heigh) as the nutritional status of children. Furthermore, relations were analyzed using spearman correlation. The result of this study showed there is no significant correlation between the internal family function ( $p=0.304 ; r=-0.065)$ and external family function $(p=0.116 ; r=-0.100)$ on the nutritional status of children. So it can be concluded that the internal family functions (APGAR) and external family function (SCREEM) did not give significant effect to the nutritional status of children in the District Soreang, Bandung. Study about family functioning by using Family APGAR dan SCREEM questionnaires need stronger analysis.
\end{abstract}

Keywords: Family APGAR, Family Functioning, Nutritional Status of Children, SCREEM.

Korespondensi:

Ulfi Ainun Hanifah

Fakultas Kedokteran, Universitas Padjadjaran

Jl. Raya Bandung-Sumedang km 21 Jatinangor

Mobile : 085294023980

Email : ulfiainunhanifah@gmail.com 


\section{Pendahuluan}

Malnutrisi merupakan suatu keadaan ketidakseimbangan antara asupan dan kebutuhan nutrisi untuk dapat memenuhi kebutuhan tubuh secara optimal, dapat berupa kelebihan ataupun kekurangan nutrisi. ${ }^{1}$ Hingga saat ini malnutrisi pada anak masih menjadi permasalahan yang serius yang dialami oleh hampir seluruh negara di dunia terutama negara-negara berkembang. ${ }^{2}$ Keadaan malnutrisi dapat ditentukan dengan mengetahui status gizi terlebih dahulu, dimana untuk menentukan status gizi suatu kelompok dilihat dari data gizi buruk kelompok tersebut. Data Riskesdas pada tahun 2010 menunjukkan prevalensi balita yang mengalami gizi kurang dan gizi buruk secara nasional adalah $17,9 \%$ dan meningkat pada tahun 2013 menjadi 19,6\%. ${ }^{3}$ Angka tersebut masih jauh dari target Millenium Development Goals 2015 dimana angka kekurangan gizi diharapkan mencapai kurang dari 15,5\%. ${ }^{3}$ Di Jawa Barat sendiri, angka kejadian gizi kurang dan buruk masih cukup tinggi yakni sebanyak 11,3\%. ${ }^{4}$ Keadaan gizi kurang dan buruk pada anak seperti ini seringkali mendapat perhatian yang lebih besar mengingat dampaknya sangat besar untuk kualitas dan harapan hidup dimana nantinya seorang anak yang akan menjadi bakal pemuda yang menjalankan masa depan bangsa.

Faktor yang dapat memengaruhi terjadinya gizi buruk dapat dibedakan menjadi faktor langsung dan tidak langsung. Faktor pengaruh langsung yang banyak terjadi diantaranya seperti kurangnya jumlah dan kualitas makanan yang dikonsumsi, riwayat penyakit infeksi atau penyakit kronik, ataupun perilaku dan pelayanan kesehatan yang kurang baik. ${ }^{5,6}$ Adapun faktor-faktor tidak langsung yang juga dapat memengaruhi terjadinya gizi buruk seperti tingkat pendidikan, tingkat sosial dan ekonomi keluarga. ${ }^{6}$ Faktor keluarga menjadi salah satu faktor penting yang perlu diperhatikan sebagai lingkungan pertama dan utama untuk seorang anak. Setiap keluarga akan memiliki fungsi untuk dapat menyeimbangkan dan menyejahterakan komponen didalamnya. Ketika fungsi sebuah keluarga bekerja dengan baik, maka segala proses yang terjadi didalamnyapun akan baik termasuk pada proses tumbuh kembang anak yang ditunjukkkan oleh status gizinya. ${ }^{7}$ Fungsi keluarga dapat dibedakan menjadi fungsi keluarga eksternal dan internal. Fungsi keluarga eksternal meliputi keadaan sosial, budaya, keagamaan, tingkat pendidikan, perekonomian keluarga hingga pengaturan dalam bidang kesehatan pada sebuah keluarga yang dapat dinilai melalui sebuah kerangka kuesioner yang disebut dengan kuesioner SCREEM (Social,Cultral, Religion,Ec onomy, Education,Medical). ${ }^{8}$

Sedangkan faktor internal keluarga meliputi faktor yang lebih menyinggung fungsi psikologis dalam keluarga, seperti kepuasan berkeluarga, cara memutuskan dan menyelesaikan masalah dalam keluarga, komunikasi antar anggota keluarga, kasih sayang, dan cara membagi waktu dalam keluarga, dimana hal tersebut dapat di ukur melalui sebuah kuesiner yaitu APGAR (Affection, Partnership, Growth, Affection, Resolve) Keluarga. ${ }^{9}$ Data dari laporan profil kesehatan Provinsi Jawa Barat menunjukkan bahwa dari hasil Bulan Penimbangan Balita tahun 2012 di Kabupaten Bandung ditemukan balita gizi kurang sebanyak $8,57 \%$ dan balita dengan gizi buruk (sangat kurus) sebesar $0,94 \% .{ }^{17}$ Hingga saat ini belum ada penelitian yang menghubungkan kedua fungsi keluarga internal dan eksternal terhadap status gizi anak. Tujuan dari penelitian ini adalah untuk mencari hubungan fungsi keluarga baik secara internal dan eksternal terhadap status gizi anak di Kecamatan Soreang, Kabupaten Bandung, tahun 2016. Selain itu, penelitian ini dapat memberikan manfaat untuk meningkatkan kesaradan masyarakat mengenai pentingnya fungsi keluarga.

\section{Metode}

Penelitian ini merupakan penelitian pada bagian kesehatan komunitas dalam tinjauan kedokteran keluarga yang tergabung dalam Academic Leadership Grant (ALG) yang memiliki judul utama penelitian "Peningkatan Kualitas Hidup Anak Dalam Tinjauan Kedokteran Keluarga di Wilayah Kecamatan Soreang Suatu Pengembangan Model Intervensi Holistik di Daerah Sub-Urban Pasca Millenium Develompent Goals" dengan populasi penelitian pasangan ibu dan anak usia balita (anak dibawah usia 5 tahun) di Kecamatan Soreang, Kabupaten Bandung pada tahun 2016. Jenis penelitian yang dilakukan adalah penelitian dengan metode potong lintang (cross sectional). Pengambilan data penelitian ini dilakukan pada bulan September-November 2016 setelah mendapat izin dari komite etik Fakultas Kedokteran, Universitas Padjadjaran dengan nomor persetujuan etik hasil amandemen 43/UN6.C1.3.2/KEPK/PN/2016.

Pemilihan subjek penelitian dilakukan dengan metode multistage random sampling. Jumlah total subjek dalam penelitian ini adalah 251 pasangan ibu dan anak balita yang ditentukan menggunakan rumus kuota minimal dengan presisi (d) $10 \%$. Kriteria inklusi dalam penelitian ini adalah pasangan ibu dan anak balita diatas usia 6 bulan 
yang memiliki Kartu Menuju Sehat (KMS) yang datanya diisi secara lengkap juga bersedia mengikuti penelitian dan menandatangani lembar persetujuan. Kriteria ekslusi dalam penelitian ini adalah pasangan yang apabila anak balitanya mengalami sakit ataupun infeksi kronis yang diketahui dari rekam medis di KMS dan pasangan yang apabila anak balitanya mengalami sakit ataupun infeksi kronis yang diketahui dari rekam medis di KMS dan pasangan yang apabila ibunya tidak dapat berkomunikasi dengan baik.

Dalam penelitian ini digunakan dua jenis kuesioner yang sudah melewati proses validasi Kuesioner terlebih dahulu, diantaranya kuesioner APGAR keluarga untuk menilai fungsi keluarga internal dan kuesioner SCREEM untuk menilai fungsi keluarga eksternal. Kuesioner tersebut diisi secara langsung oleh responden (ibu). Kuesioner APGAR keluarga merupakan salah satu alat yang digunakan untuk menilai fungsi internal keluarga dengan menilai fungsi afeksi atau perhatian, hubungan kerjasama, pertumbuhan, cara menangani masalah dan membagi waktu dalam keluarga. Kuesioner SCREEM digunakan untuk menilai fungsi eksternal keluarga dengan menilai aspek sosial, budaya, religi, ekonomi, pendidikan dan kesehatan dalam keluarga. Skor minimal pada kuesioner APGAR adalah 0 dan skor maksimalnya adalah 10 . Interpretasi dari skor APGAR keluarga ini adalah sebagai berikut, keluarga fungsional (7-10) dan tidak fungsional (06). Level ketidak fungsionalan didalam kuesiner APGAR terbagi menjadi 2 kategori, kurang fungsional (4-6) dan sangat tidak fungsional (04). Pada Kuesioner SCREEM, penilaian fungsi keluarga melihat sisi patologis dari setiap aspek fungsi, sehingga semakin besar skor menandakan keluarga semakin tidak fungsional dan sebaliknya. Skor minimal pada kuesioner SCREEM adalah 0 dan skor maksimal adalah 6 . Interpretasi pada kuesioner SCREEM dapat dilakukan secara menyeluruh ataupun dari masing-masing aspek. Fungsi keluarga mendukung (0-2) dan tidak tidak mendukung (3-6). Sedangkan untuk setiap aspeknya, peneliti mengembangkan pertanyaan dari framework SCREEM yang sudah ada sebelumnya, yang selanjutnya divalidasi. Setiap aspek dikembangkan kedalam 3 pernyataan sehingga akan didapat inerpretasi mendukung (0-1) dan tidak mendukung (2-3) pada setiap aspeknya.

Selanjutnya hasil dari skor fungsi keluarga dicari hubungannya dengan status gizi anak yang didapat dari hasil pengukuran antropometri (berat badan dan tinggi badan) yang dilakukan pada satu waktu (penelitian potong lintang/cross sectional). Status gizi didapatkan dengan mengkalkulasikan hasil pengukuran berat dan tinggi badan menjadi nilai standar deviasi (Z score berat terhadap tinggi badan) sebagai variabel numeric, dimana dapat diinterpretasikan sebagai gizi lebih $(>+2 \mathrm{SD})$, gizi baik $(-2 \geq \mathrm{SD} \geq+2)$, gizi kurang $(\mathrm{SD}<-2)$ dan gizi buruk $(\mathrm{SD}<-3)$. Selanjutnya dilakukan analisis hubungan antara kedua variabel numerik yakni fungsi internal dan eksternal keluarga dengan status gizi anak menggunakan uji korelasi spearman.

\section{Hasil}

Penelitian ini mengikutsertakan 251 pasangan ibu dan anak balita di 10 desa Kecamatan Soreang pada tahun 2016. Data penelitian berasal dari data primer berupa kuesioner serta data dari pengukuran tinggi dan berat badan anak balita yang terpilih sebagai responden. Proses uji validasi maupun analisis data dilakukan dengan bantuan program SPSS 21.

Tabel 1 Karakteristik Sampel Penelitian

\begin{tabular}{lc}
\hline Karakteristik & Frekuensi (\%) \\
\hline Kelompok Usia (N=251) & $36(14,3)$ \\
6-11 bulan & $80(31,9)$ \\
$12-23$ bulan & $135(53,8)$ \\
24-59 bulan & \\
Jenis Kelamin & $117(46,6)$ \\
Laki- laki & $134(53,4)$ \\
Perempuan & \\
Jumlah Anak (N=251) & $195(77,7)$ \\
$\leq 2$ anak & $56(22,3)$ \\
3-5 anak & $0(0)$ \\
$>5$ anak & \\
Penghasilan Keluarga (N=251) & $51(20,3)$ \\
Diatas UMK & $200(79,7)$ \\
Dibawah UMK & \\
Status Gizi Anak (N=251) & $16(6,4)$ \\
Gizi Lebih & $203(80,9)$ \\
Gizi Baik & $24(9,6)$ \\
Gizi Kurang & $8(3,1)$ \\
Gizi Buruk & $180(71,7)$ \\
APGAR Keluarga & $71(28,3)$ \\
Fungsional & \\
Tidak Fungsional & $250(99,6)$ \\
SCREEM & $1(0,4)$ \\
Mendukung & \\
Tidak Mendukung &
\end{tabular}


Ulfi Ainun Hanifah : Hubungan Fungsi Keluarga dengan Status Gizi Anak di Kecamatan Soreang Kabupaten Bandung pada Tahun 2016

Tabel 2 Hubungan Aspek Fungsi Internal dan Ekternal Keluarga terhadap Status Gizi Anak

\begin{tabular}{lcc}
\hline \multicolumn{1}{c}{ Aspek Fungsi Keluarga terhadap Status Gizi } & $\mathrm{p}$ & Nilai Korelasi Spearman \\
\hline Fungsi Internal Keluarga (APGAR) - Keseluruhan & 0,304 & $-0,065$ \\
Adaptasi (Adaptation) & $0,030 * *$ & $-0,186$ \\
Kerjasama Keluarga (Partnership) & 0,462 & 0,047 \\
Pertumbuhan (Growth) & 0,230 & $-0,076$ \\
Perhatian dan Kasih Sayang (Affection) & 0,965 & 0,003 \\
Pemecahan Masalah (Resolve) & 0,940 & $-0,005$ \\
Fungsi Ekternal Keluarga (SCREEM) - Keseluruhan & 0,116 & $-0,100$ \\
Sosial (Social) & 0,242 & 0,074 \\
Budaya (Cultural) & 0,397 & 0,053 \\
Agama (Religion) & $-*$ & $-*$ \\
Ekonomi (Economy) & 0,160 & $-0,089$ \\
Pendidikan (Education) & 0,377 & $-0,056$ \\
Kesehatan (Medical) & 0,720 & $-0,023$ \\
\hline
\end{tabular}

(*) Tidak dapat didefinisikan karena nilai selalu konstan.

(**) Signifikan pada 0,01

Responden yang menjadi subjek dalam penelitian Kuesioner yang digunakan dalam penelitian ini sudah melewati uji validitas dan reliabilitas sebelumnya dengan indikator pearson. ini dikarakteristikan berdasarkan jenis kelamin, kelompok usia, jumlah anak dan penghasilan keluarga.

Tabel 1 menunjukkan bahwa melebihi separuh responden berusia 24-59 bulan (53,8\%). Sebagian besar anak yang menjadi responden dalam penelitian ini adalah perempuan $(53,4 \%)$. Hanya sebagian kecil dari responden yang memiliki jumlah anak melebihi 2 orang anak $(22,3 \%)$. Dari keseluruhan responden penelitian terdapat 200 keluarga $(79,7 \%)$ yang memiliki penghasilan di atas UMR (Upah Minimum Ratarata) dan sebagian besar responden memiliki status gizi baik $(80,9 \%)$. Kebanyakan responden memiliki keluarga yang fungsional secara internal $(71,7 \%)$ dan memiliki fungsi yang mendukung pula secara eksternal $(99,6 \%)$. Dalam penelitian ini, data yang didapatkan memiliki sebaran yang tidak merata yang ditunjukkan pada nilai hasil uji normalitas yang kurang dari 0,05 sehingga analisis hubungan atau korelasi antar variabel dilakukan dengan uji korelasi spearman.

Pada tabel 1 didapatkan bahwa seluruh aspek fungsi keluarga internal dan eksternal baik secara keseluruhan maupun setiap aspeknya masing-masing memiliki nilai $\mathrm{p}>0,05$ yang menunjukkan bahwa fungsi internal dan eksternal keluarga tersebut tidak memiliki hubungan yang signifikan terhadap status gizi. Nilai korelasi spearman pada tabel diatas menunjukkan kekuatan korelasi antara variabel terikat (status gizi) dengan variabel bebas (fungsi internal dan eksternal keluarga). Dapat dilihat pada tabel 1. nilai korelasi spearman pada fungsi internal keluarga (APGAR) secara keseluruhan, juga pada beberapa aspek fungsinya diantaranya fungsi adaptasi $(-0,186)$, pertumbuhan $(-0,076)$ dan pemecahan masalah $(-0,005)$ memiliki nilai negatif yang artinya bila ditemukan korelasi dengan variabel dependennya (status gizi) maka akan mengarah kearah sebalikanya. Begitupun makna pada aspek fungsi kerjasama dan afeksi juga kasih sayang keluraga yang memiliki nilai korelasi positif yang bermakna hubungan dengan variabel dependennya berjalan searah.

Hubungan fungsi eksternal keluarga (SCREEM) secara keseluruhan dengan status gizi juga memiliki hubungan yang tidak bermakna. Begitu juga hubungan pada setiap aspeknya dimana nilai $\mathrm{p}$ yang didapat melebihi nilai 0,05 . Sama halnya dengan fungsi internal keluarga, aspek pada fungsi eksternal keluarga juga memiliki nilai korelasi yang cenderung ke arah negatif, yakni pada aspek fungsi ekonomi $(-0,089)$, pendidikan $(-0,056)$, dan kesehatan $(-0,023)$. Sedangkan, pada aspek fungsi sosial dan budaya korelasi bernilai positif $(0,074 ; 0,054)$. Pada aspek fungsi keagamaan, nilai korelasi maupun nilai $\mathrm{p}$ tidak dapat diidentifiksi disebabkan karena tidak adanya variasi data dimana semua responden mengisi jawaban yang sama. Pada fungsi internal keluarga, dapat dilihat bahwa semua aspek fungsinya memiliki nilai korelasi yang jauh dari nilai 1 untuk korelasi positif dan jauh dari nilai -1 untuk korelasi negatif yang artinya kekuatan korelasi atau hubungannya dengan variabel 
dependen (status gizi) sangat lemah. Korelasi pada fungsi eksternal keluarga (SCREEM) juga baik secara keseluruhan maupun setiap aspeknya terhadap status gizi memiliki kekuatan yang sangat lemah karena nilainya yang menjauhi -1 dan atau 1.

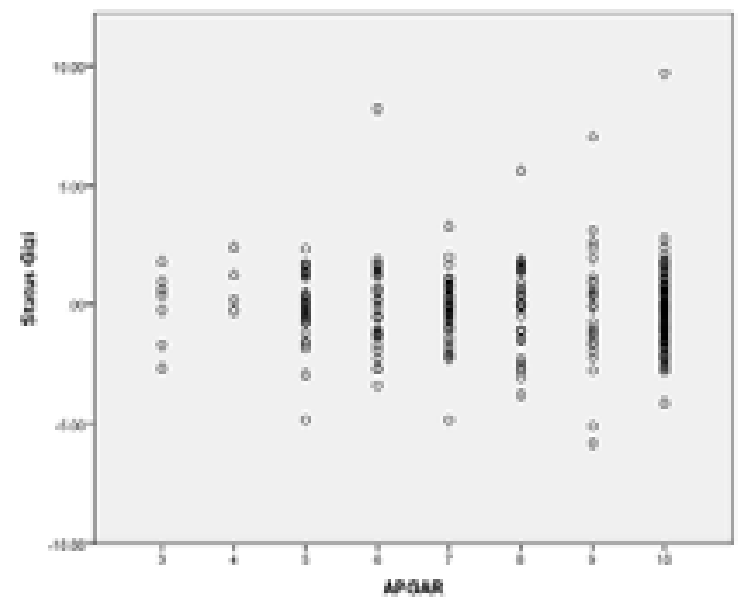

Gambar 1 Grafik scatter plot hubungan fungsi internal keluarga (APGAR) dengan status gizi.

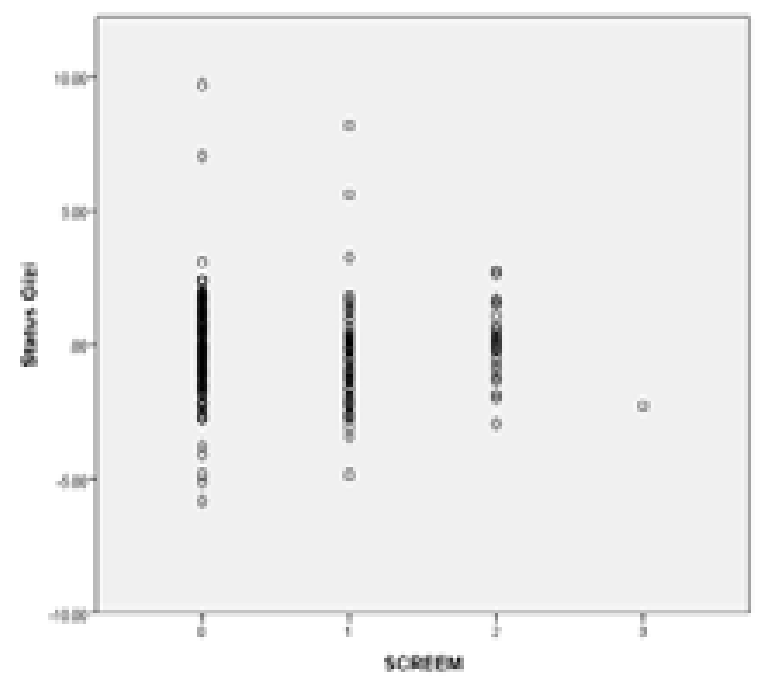

Gambar 2 Grafik scatter plot hubungan fungsi eksternal keluarga (SCREEM) dengan status gizi.

Pada kedua gambar diatas dapat dilihat persebaran data yang tidak merata dimana hal ini dapat dipicu karena jawaban responden dalam penelitian ini baik pada kusioner penilaian fungsi keluarga internal (APGAR) maupun eksternal (SCREEM) mengarah kepada jawaban yang sama, sesuai dengan hasil uji normalitas yang menunjukkan ketidak normalan persebaran data.
Selain itu, kedua grafik diatas memperlihatkan hubungan atau korelasi antara variabel dependen (status gizi) dan independen (fungsi internal dan eksternal keluarga) secara keseluruhan dimana grafik tidak menunjukkan hubungan yang bermakna baik kearah hubungan positif ataupun negatif.

\section{Pembahasan}

Dari hasil penelitian ini didapatkan hampir semua sampel memiliki keluarga yang fungsional. Setelah dianalisis dalam penelitian ini didapatkan bahwa aspek- aspek fungsi keluarga memiliki hubungan yang tidak signifikan terhadap status gizi. Hal ini tidak menggambarkan sebagaimana yang disebutkan oleh UNICEF bahwa terdapat faktor-faktor yang dapat memengaruhi status gizi yang merupakan faktor tidak langsung yang berasal dari keluarga. ${ }^{5}$ yang mana dalam penelitian ini faktor tersebut adalah fungsi keluarga secara internal (APGAR) dan eksternal (SCREEM). ${ }^{10}$

Hasil penelitian menghasilkan nilai $\mathrm{p}$ yang lebih dari 0,05 yang menunjukkan tidak adanya hubungan yang signifikan antara fungsi keluarga dengan status gizi. Selain itu, nilai korelasi spearman pada beberapa aspek fungsi keluarga bernilai negatif yang maknanya korelasi antar variabel berjalan sebaliknya. Nilai korelasi yang didapatkan dalam analisis penelitian ini juga menunjukkan kekuatan korelasi yang sangat lemah karena menjauhi nilai 1 pada referensinya masing-masing baik untuk referensi hubungan negatif maupun positif.

Tidak adanya hubungan yang signifikan antara fungsi keluarga yang mencakup aspek yang cukup luas seperti fungsi sosial, budaya, ekonomi, pendidikan, pengasuhan, kesehatan dan lainnya terhadap status gizi anak ini sejalan dengan penelitian mengenai hubungan fungsi dan tugas kesehatan keluarga, karakteristik keluarga dan anak dengan status gizi balita di wilayah Puskesmas Pancoran Mas Kota Depok yang dilakukan oleh Rina Nur Hidayat yang menunjukkan hasil serupa bahwa tidak didapatkan hubungan atau pengaruh dari fungsi keluarga dengan status gizi anak. Dalam penelitiannya dikatakan bahwa hal tersebut sangat mungkin terjadi karena penyebab masalah gizi, baik gizi kurang, gizi buruk ataupun gizi lebih adalah permasalahan multisektor. Masalah gizi pada balita terjadi disebabkan oleh banyak faktor yang saling berkaitan dan tidak berdiri sendiri.

Adapun beberapa penelitian yang hasilnya tidak sesuai dan tidak mendukung penelitian ini, seperti pada penelitian yang dilakukan oleh 
Zulfikar Adi Gumawang dkk pada tahun 2016 mengenai Hubungan Antara Fungsi Keluarga dengan Status Gizi Anak pada Murid Sekolah Dasar SDN 5 Boyolali, dimana dalam penelitian tersebut didapatkan kesimpulan didapatkannya hubungan yang signifikan antara fungsi keluarga dengan status gizi anak. ${ }^{11}$

Pada beberapa penelitian yang telah dilaksanakan mengenai hubungan aspek fungsi keluarga terhadap status gizi, pada umumnya lebih banyak penelitian yang membahas dan meneliti dari sisi fungsi eksternal. Sebelumnya, belum pernah dilakukan penelitian serupa yang mencari hubungan antara fungsi internal keluarga (APGAR) sekaligus fungsi eksternal keluarga (SCREEM) dengan status gizi anak balita di daerah urban. Kebanyakan penelitian yang sudah dilakukan sebelumnya, menghubungkan fungsi internal keluarga (APGAR) dengan penyakitpenyakit kronis ataupun permasalahan kesehatan yang berkaitan dengan kualitas hidup. Seperti penelitian yang telah dilakukan oleh Ekawati Sutiknopada tahun2011 dimanapenelitiantersebut bertujuan mencari hubungan fungsi keluarga dengan kualitas hidup lansia pada kelompok jantung sehat di kota Kediri. Dari penelitian tersebut didapatkan pengaruh positif yang kuat mengenai fungsi internal keluarga (APGAR) terhadap kualitas hidup lansia. ${ }^{12}$ Malnutrisi sebenarnya juga merupakan permasalahan kesehatan kronik, hal ini disebabkan oleh proses kejadiannya yang merupakan akibat dari paparan suatu faktor dalam jangka waktu yang cukup lama sehingga menimbulkan manifestasi.

Hasil analisis yang didapat pada penelitian ini tidak sesuai dengan hipotesis yang diharapkan (H1) dan tidak dapat mematahkan hipotesis nol (H0) pada awal penelitian dimana tidak terdapat hubungan yang signifikan antara fungsi keluarga dengan status gizi anak. Hal ini dapat disebabkan beberapa hal seperti adanya faktor langsung maupun tidak langsung yang memengaruhi lebih kuat dan signifikan terhadap status gizi responden. Selain itu kekurangan dalam penelitian ini juga dapat menjadi faktor lain yang menjadikan hasil dari penelitian ini tidak sesuai dengan hasil pada penelitian- penelitian sebelumnya.

Keterbatasan dalam penelitian ini adalah kurangnya eksplorasi dan penilaian fungsi keluarga yang mana secara ideal, penilaian fungsi keluarga dengan menggunakan kuesioner ini dilakukan dengan menanyakan pertanyaan dalam kuesioner pada semua anggota keluarga, namun dalam penelitian ini hanya ditanyakan pada salah satu anggota keluarga saja yaitu ibu, sehingga masih mungkin terjadinya penilaian subjektif dari satu anggota keluarga yang memungkinkan adanya penilaian yang berbeda dari anggota keluarga yang lain. Selain itu, kuesioner ini memiliki pilihan jawaban yang membutuhkan pengukuran presepsi yang mana hal tersebut juga merupakan subjektifitas dari setiap responden.

Penelitian ini diharapkan dapat menjadi bahan ataupun referensi pembanding dalam pengembangan penelitian-penelitian lainnya, juga untuk mengeksplorasi pengembangan program peningkatan fungsi keluarga dimana dari penelitian ini diketahui fungsi-fungsi apa saja yang sepatutnya dimiliki sebagai keluarga yang fungsional.

Kesimpulan yang didapatkan dari penelitian ini, adalah fungsi internal keluraga (APGAR) dan fungsi eksternal kelurga (SCREEM) tidak memiliki hubungan yang signifikan terhadap status gizi anak di Kecamatan Soreang, Kabupaten Bandung, Namun, diperlukan analisis dan pengembangan yang lebih lanjut mengenai kuesioner yang digunakan untuk melakukan penilaian fungsi keluarga.

\section{Ucapan Terima Kasih}

Penulis mengucapkan terima Kasih kepada Dany Hilmanto, yang telah memfasilitasi penelitian ini melalui proyek penelitian dengan dana yang berasal dari Academic Leadership Grant Universitas Padjadjaran

\section{Daftar Pustaka}

1. Whitney E, Rolfes SR. Understanding Nutrition. 14th ed. Cengage Learning;2015

2. United Nations International Chindren's Emergency Fund. Under nutrition contributes to nearly half of all deaths in children under 5 and is widespread in Asia and Africa New York. 2015;1

3. Badan Penelitian dan Pengembangan Kesehatan Kementrian Kesehatan Republik Indonesia Tahun 2013 (Riset Kesehatan Dasar).2013.Kementrian Kesehatan RI;2013:211

4. Heny Lestary D. Riset Kesehatan Dasar dalam Angka Provinsi Jawa Barat.2013:172

5. Alison Shepherd. Nutrition support, Risk Factors, Causes and Physiology of malnutrition. 2009:18-20

6. Bahawaludin J, Arbab A, Shankar L, Ghulam R, Shaifulah J.Risk Factor for sever Acute Malnutrition in Children Under the Age of Five Year in Sukkur.Pakistan Jurnal of Medical Research.2012.51:111-113.

7. Lestari. Psikologi Keluarga. Jakarta: Kencana 
Prenada Media Grup; 2012

8. Pineda A. Tools for family assessment. In PAFP Proceedings of the Orientation Course in Family Medicine. Edited by: Bugayong R, Pineda A. Makati City: Philippine Academy of Family Physicians; 1999:36-50

9. Hiroaki TN. The Most Important Question in Family approach: the potential of the resolve item of the family APGAR in family medicine. 2016:1-2.

10. Suprajitno, S.Kp. Asuhan Keperawatan Keluarga, Edisi 1. Jakarta: ECG. 2004.hlm.1-
18.

11. Hidayati R. Hubungan Fungsi dan Tugas Kesehatan Keluarga, Karakteristik Keluarga dan Anak dengan Status Gizi Balita di Wilayah Puskesmas Pancoran Mas Kota Depok. 2011;1:1-3.

12. Gumawang ZA. Hubungan Fungsi Keluarga dengan Status Gizi Anak pada Murid di SDN 5 Kediri. 2016;1-4.

13. Sutikno E. Hubungan Fugsi Keluarga dengan Kualitas Hidup Lansia. 2011;1-4. 